\title{
Bone Marrow Flow Cytometry
}

National Cancer Institute

\section{Source}

National Cancer Institute. Bone Marrow Flow Cytometry. NCI Thesaurus. Code C38063.

Flow cytometry using cells derived from a bone marrow sample. 